\title{
THE ROLE OF KNOWLEDGE ACQUISITION IN A COMPANY - RESEARCH RESULTS FROM GERMAN AND POLISH MANUFACTURING COMPANIES
}

\author{
Justyna PATALAS-MALISZEWSKA*, Małgorzata ŚLIWA** \\ University of Zielona Góra, Zielona Góra, Poland \\ e-mail: j.patalas@iizp.uz.zgora.pl \\ e-mail: m.sliwa@iizp.uz.zgora.pl
}

\begin{abstract}
This article elaborates the authors' method for tacit knowledge acquisition focused on a research and development department in a manufacturing company. It presents a case study of the use of concepts for tacit knowledge acquisition and is based on a survey and data obtained from 85 Polish and German Manufacturing Companies from the cross-border cooperation region of Lubuskie/Poland Brandenburg/Germany. This article develops a framework of tacit knowledge acquisition in a manufacturing company and further discusses the research results.
\end{abstract}

Keywords: tacit knowledge, knowledge acquisition, research and development department, manufacturing company.

1

Introduction

For manufacturing companies functioning in the knowledge-based economy, their knowledge is now known as a key source for their development (Nycz, 2011). Moreover, knowledge is also the main source for any action in innovative enterprises and can increase the market value of a company (Drucker, 1964). The implementation of new tasks in a company is frequently based on interdisciplinary knowledge that is rooted in the minds of different specialists. According to Wasowicz (2013), knowledge should be accumulated to create a possibility of the exchange of experience gained from working on projects within a company. Knowledge is defined as consisting of tacit knowledge (acquired from employees) and explicit knowledge (defined in the form of company policies, regulations, procedures, policies, etc.). In this paper, special attention is paid to tacit knowledge acquisition. Additionally, knowledge in a company can be obtained from internal sources of the company as well as from external sources (Prodan, CoticSvetina, 2008; PatalasMaliszewska and Krebs, 2015). Our motivation to study this approach came from the research results obtained from Polish and German manufacturing companies ${ }^{1}$.

\footnotetext{
${ }^{1}$ This work was supported in part by the project realized by Justyna Patalas-Maliszewska: "Assessing the relationship be-
}

A manufacturing company needs to develop methods to acquire knowledge, especially tacit knowledge. According to Maurer (2010), knowledge acquisition can increase the success of research and development (R\&D) projects. This study focuses on the relationships between tacit knowledge acquisitions from identified tacit knowledge sources with factors describing any realized R\&D project success. The quest to describe relationships, especially how they lead to an increase of R\&D projects in manufacturing companies, was motivated by the authors' research to build a model and method for tacit knowledge acquisition for R\&D departments in manufacturing companies.

Using survey data from 62 Polish manufacturing companies from the Lubuskie region and from 23 German manufacturing companies from the Brandenburg region, this study discusses the main tacit knowledge sources in a manufacturing company and how they affect project realization in the crossborder cooperative region of Lubuskie/PolandBrandenburg/Germany. The research companies are from the automotive and construction sectors and constitute $20 \%$ of such enterprises in the crossborder cooperative region.

tween business strategy and knowledge transfer in German Manufacturing Enterprises" by the German Academic Exchange Service (DAAD), Bonn, Germany, Nr: 235585, 2016. 
Chapter 2 provides literature studies related to tacit knowledge acquisition in a manufacturing company. Chapter 3 presents the main tacit knowledge sources within a company and outside of a company based on the research results from German and Polish manufacturing companies and also formulates the effects of knowledge acquisition from the main sources in Polish and German manufacturing companies. Chapter 4 develops the authors' method for tacit knowledge acquisition focused on an R\&D department in a manufacturing company and, finally, presents a case study of the use of presented concepts for tacit knowledge acquisition. Chapter 5 summarizes the research results.

\section{Tacit Knowledge acquisition in a manufac- turing company - related work}

The implementation of knowledge acquisition and transfer methods or systems in an organization can lead to an improvement in realized innovative projects (Wangare et al., 2013). Knowledge storage is especially important in the case of mergers, acquisitions by other companies, opening new or similar units, suspension of business, loss of possessions as a result of natural disasters or political conflict, and so on and also in the realization of operational tasks in each department. Regular knowledge acquisition prevents the occurrence of information gaps and may save a company from the effects of the loss of a key specialist. Knowledge collection and sharing facilitates the achievement of business benefits resulting mainly from a reduction in process duration, fewer complaints, a faster implementation of new knowledge workers, external consultation and training-time reduction, an optimal choice of technologies, material flows, and others (Tabaszewska, 2008; Gasik, 2011).

Table 1 shows the types of knowledge stored in a manufacturing enterprise and indicates internal and external sources (Falkenberg et al., 2003) depending on their location (Belussi et al., 2005), including a classification of tacit and explicit knowledge.

Table 1 . The types of knowledge acquired in a manufacturing company

\begin{tabular}{|c|c|c|}
\hline & External types of knowledge & Internal types of knowledge \\
\hline Explicit & $\begin{array}{l}\text { - Regulations } \\
\text { - Standards and quality requirements } \\
\text { - Requirements defined by a customer } \\
\text { - Material specifications } \\
\text { - Characteristics of competitors and self- } \\
\text { presentation of competitive enterprises }\end{array}$ & $\begin{array}{l}\text { - Reports } \\
\text { - Forms } \\
\text { - Instructions } \\
\text { - Intranet } \\
\text { - Flow maps } \\
\text { - Technical documentation of projects } \\
\text { - Internal knowledge base }\end{array}$ \\
\hline Tacit & $\begin{array}{l}\text { - Feedback from customers and suppliers } \\
\text { - Consultation, analysis (e.g., obtained from } \\
\text { research and development units) }\end{array}$ & $\begin{array}{l}\text { - Simulation results } \\
\text { - The results of analyses (quality, strength, } \\
\text { etc.) }\end{array}$ \\
\hline
\end{tabular}

As a result, the knowledge that was accumulated in the organization and properly classified can act as an intangible fixed asset.

The acquisition of external knowledge in a company is associated with its accumulation in the minds of employees, for example, the training of employees or keeping it in the form of digital media that is more stable and possible to replicate. Knowledge obtained from diffuse sources, for example, Web pages, expert services, and knowledge bases can be selectively adjusted to our needs. Of great use are algorithms whose task is to identify keywords, including the frequency of their incidence or referring to their fixed sequences (semantic methods: Bergamaschi 
et al., 2012; and data mining techniques: Han, Kamber, Pei, 2012). In order to systematize knowledge, Bayes networks (Olbryś, 2007; Śliwa, PatalasMaliszewska, 2015), genetic algorithms (Hu, Yang, 2004), or decision trees are also used. In a manufacturing company, such mechanisms are rarely used. Most often essential knowledge is obtained via employee contact with other colleagues or with the external environment of a company. In a small and medium (SME)-sized production company, the most common ways of acquiring knowledge are:

a) sending offers of requests,

b) requesting access to external databases (e.g., parts catalogues, technical parameters),

c) asking about access to applications on the Web pages of suppliers' machine parts. For example, in the case of the selection of a suitable pneumatic actuator, designers can log onto the manufacturer's Web site to determine the operating parameters and the basic specifics and then generate a downloadable 3D model that the manufacturer is able to deliver,

d) simulation of physical phenomena by using external applications. For example, in the case of selecting the appropriate glass (raw material), light transmission should be analyzed (as required by Polish legal regulations: Ministry of the Regulation of Infrastructure from December 31, 2002, about the technical conditions of vehicles and obligatory equipment). It is possible after entering the parameters of glass, thickness, type, and tint, to simulate its translucency.

Access to tacit knowledge is described as difficult, and its possession is bound up with the question of experience. In the case of the intended acquisition of this type of resource, it should focus on the observation (used in expert systems: Marcus, 1988; Duda, 2015), demonstration, or analysis of the processes or activities that lead to the required effect. In a general classification, the acquisition of tacit knowledge in an enterprise can be assumed to consist of:

a) observations - conducted in real time and using record analysis,

b) demonstrations and training,

c) knowledge audits, d) audio or video recordings - which would rely on the search of dependence in clearly undefined processes, in activities performed in a different way, which earlier only paid attention to the final result (Patalas-Maliszewska and Dudek, 2016).

The selection of methods for supporting tacit knowledge elicitation should correspond with the technology used in a company, taking into account the type of generated files and the specificity of work. Elements that support the accumulation and simple classification of knowledge are reports, forms, and questionnaires. Other methods and tools for tacit knowledge acquisition in a manufacturing company are dependent on the company's needs and the tools that it has. These are:

- maps of processes, flows of materials and diagrams,

- video recordings of activities by experienced employees,

- sound tracks,

- the recording of logs generated by specialists performing creative work,

- representations of models, visualization, holograms, and virtual environments.

In our study, we are seeking a method for tacit knowledge acquisition for an R\&D department in a manufacturing company. According to the results of the literature study, the following conceptual model has been defined.

\section{A conceptual model based on the research results}

Tacit knowledge acquisition can be one of the critical success factors for R\&D projects (Diallo and Thuillier, 2005). An approach of this study is that it presents the importance of tacit knowledge sources for tacit knowledge acquisition in a company and explains which knowledge source can support the realization of $R \& D$ projects in a manufacturing company. Fig. 1 indicates the knowledge available to an organization from the outside and that which is possible to acquire inside the company. R\&D institutions and external experts were identified as being external sources of tacit knowledge. 


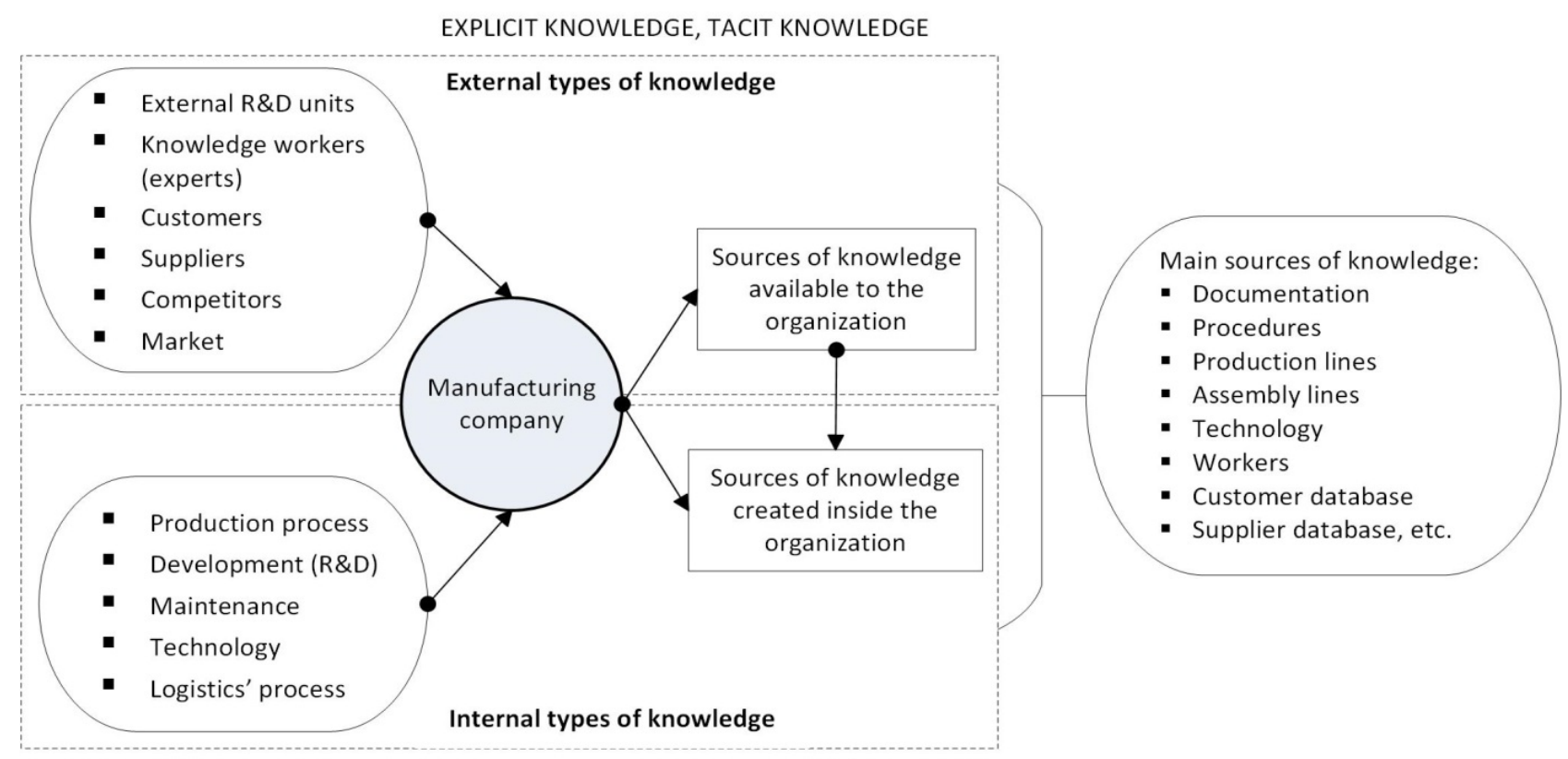

EXPLICIT KNOWLEDGE, TACIT KNOWLEDGE

Figure 1. A conceptual model

In turn, employees of various departments act as sources of tacit knowledge in the company.

According to the results of the literature study, it is possible to define a conceptual model (Fig. 1).

In order to build the research model, survey data were collected from 85 manufacturing enterprises from the Lubuskie, Poland, and Brandenburg, Germany, cross-border cooperative region where a number of companies were defined as being either construction or automotive (a total of $20 \%$ of such companies were surveyed). The research group was studied in the form of direct meetings, an e-mail survey, and a phone survey. The respondents consisted of managers (over 80\%) and chief executive officers $^{2}$.

The importance of knowledge sources include five key items that describe a firm's ability to acquire tacit knowledge:

- KS-KA-factor1: I know that in my department, my knowledge is not important for supporting the realization of $R \& D$ projects,

\footnotetext{
${ }^{2}$ This work was supported in part by the project realized by Justyna Patalas-Maliszewska: "Assessing the relationship between business strategy and knowledge transfer in German Manufacturing Enterprises" by the German Academic Exchange Service (DAAD), Bonn, Germany, Nr: 235585, 2016.
}

- KS-KA-factor2: I know that in my department, my knowledge is not very important for supporting the realization of $R \& D$ projects,

- KS-KA-factor3: I know that in my department, my knowledge is marginally important for supporting the realization of $R \& D$ projects,

- KS-KA-factor4: I know that in my department, my knowledge is important for supporting the realization of R\&D projects,

- KS-KA-factor5: I know that in my department, my knowledge is very important for supporting the realization of $R \& D$ projects.

The following tacit knowledge sources are defined. Internal tacit knowledge sources are

- $\mathrm{KS}-\mathrm{KA}_{1}$ - manager,

- $\mathrm{KS}-\mathrm{KA}_{2}$ - workers in the sales department,

- $\mathrm{KS}-\mathrm{KA}_{3}$ - workers in the production department,

- $\mathrm{KS}-\mathrm{KA}_{4}$ - workers in the purchasing department,

- $\mathrm{KS}^{-} \mathrm{KA}_{5}-$ workers in the research and development department,

- $\mathrm{KS}_{-} \mathrm{KA}_{6}-$ workers in the service department.

External tacit knowledge source is

- $\mathrm{KS}_{-} \mathrm{KA}_{7}-$ external R\&D units. 
Improving the realization of $\mathrm{R} \& \mathrm{D}$ projects also includes five items:

- IRD-factor1: I do not know that my work influences the success of the realization of $R \& D$ projects in my company.

- IRD-factor2: I know only a little that my work influences the success of the realization of R\&D projects in my company.

- IRD-factor3: I know marginally that my work influences the success of the realization of R\&D projects in my company.

- IRD-factor4: I know well that my work influences the success of the realization of $R \& D$ projects in my company.
- IRD-factor5: I know very well that my work influences the success of the realization of R\&D projects in my company.

A five-point Likert scale was adopted in which 1 strongly disagree and 5 strongly agree for all items that were measured.

Statistica ver.12.5 was used to build a conceptual model. By proposing a model that addresses the identification of tacit knowledge sources, this study contributes to a filling of the gap that exists in the literature of useful knowledge in a company. Table 2 presents descriptive correlations for the main variables.

Table 2. Research results

\begin{tabular}{|c|c|c|c|c|c|}
\hline \multicolumn{2}{|c|}{$\begin{array}{l}\text { Construct/Item: } \\
\text { KS-KA-factor1/KS-KA-factor2/KS-KA-factor3/ } \\
\text { KS-KA-factor4/KS-KA-factor5 } \\
\text { IRD-factor1/IRD-factor2/IRD-factor3/IRD-factor4/IRD- } \\
\text { factor5 }\end{array}$} & \multirow{2}{*}{$\begin{array}{l}\text { Correlation } \\
0.201299\end{array}$} & \multirow{2}{*}{$\begin{array}{c}\mathrm{r} 2 \\
0.040521\end{array}$} & \multirow{2}{*}{$\begin{array}{c}\mathrm{t} \\
1.59184\end{array}$} & \multirow{2}{*}{$\begin{array}{c}\mathrm{p} \\
0.116676\end{array}$} \\
\hline Polish manufacturing companies: & $\mathrm{KS}-\mathrm{KA}_{1} / \mathrm{IRD}$ & & & & \\
\hline German manufacturing companies: & $\mathrm{KS}-\mathrm{KA}_{1} / \mathrm{IRD}$ & 0.435817 & 0.189936 & 2.218982 & 0.037638 \\
\hline Polish manufacturing companies: & $\mathrm{KS}-\mathrm{KA}_{2} / \mathrm{IRD}$ & 0.021657 & 0.000469 & 0.16780 & 0.867307 \\
\hline German manufacturing companies: & $\mathrm{KS}-\mathrm{KA}_{2} / \mathrm{IRD}$ & 0.589655 & 0.347693 & 3.345660 & 0.003065 \\
\hline Polish manufacturing companies: & $\mathrm{KS}-\mathrm{KA}_{3} / \mathrm{IRD}$ & -0.165604 & 0.027425 & -1.30072 & 0.198328 \\
\hline German manufacturing companies: & $\mathrm{KS}-\mathrm{KA}_{3} / \mathrm{IRD}$ & 0.458098 & 0.209854 & 2.361645 & 0.027932 \\
\hline Polish manufacturing companies: & $\mathrm{KS}-\mathrm{KA}_{4} / \mathrm{IRD}$ & -0.036074 & 0.001301 & -0.27961 & 0.780738 \\
\hline German manufacturing companies: & $\mathrm{KS}-\mathrm{KA}_{4} / \mathrm{IRD}$ & 0.435499 & 0.189660 & 2.216989 & 0.037793 \\
\hline Polish manufacturing companies: & $\mathrm{KS}-\mathrm{KA}_{5} / \mathrm{IRD}$ & 0.424825 & 0.180476 & 3.63500 & 0.000578 \\
\hline German manufacturing companies: & $\mathrm{KS}-\mathrm{KA}_{5} / \mathrm{IRD}$ & 0.144832 & 0.020976 & 0.670775 & 0.509675 \\
\hline Polish manufacturing companies: & $\mathrm{KS}-\mathrm{KA}_{6} / \mathrm{IRD}$ & 0.162454 & 0.026391 & 1.27530 & 0.207117 \\
\hline German manufacturing companies: & $\mathrm{KS}-\mathrm{KA}_{6} / \mathrm{IRD}$ & 0.320162 & 0.102504 & 1.548688 & 0.136396 \\
\hline Polish manufacturing companies: & $\mathrm{KS}-\mathrm{KA}_{7} / \mathrm{IRD}$ & 0.103155 & 0.010641 & 0.80332 & 0.424962 \\
\hline German manufacturing companies: & $\mathrm{KS}-\mathrm{KA}_{7} / \mathrm{IRD}$ & 0.505647 & 0.255679 & 2.685820 & 0.013838 \\
\hline
\end{tabular}


Our research results present the effects of knowledge acquisition from the main sources in Polish and German manufacturing companies on the improvement of project realization in a company. In Polish manufacturing companies, we can observe only one significant relationship: knowledge acquisition from workers who work in the R\&D department, defined as the main tacit knowledge source, can positively influence the improvement of the realization of $R \& D$ projects (corr $=0.4248)$. It is a natural result; however, this assumption requires that an awareness of the importance of knowledge in Polish companies should still be built and developed.

In German companies, we can observe the following significant interactions:

- knowledge acquisition from managers, defined as a main tacit knowledge source, can positively influence the realization of $\mathrm{R} \& \mathrm{D}$ projects (corr $=$ 0.4358),

- knowledge acquisition from workers who work in the sales department, defined as a main tacit knowledge source, can positively influence the realization of $R \& D$ projects (corr $=0.5897$ ),

- knowledge acquisition from workers who work in the production department, defined as a main tacit knowledge source, can positively influence the realization of $R \& D$ projects $(\operatorname{corr}=0.4581)$,

- knowledge acquisition from workers who work in the purchasing department, defined as a main tacit knowledge source, can positively influence the realization of $R \& D$ projects ( $\operatorname{corr}=0.4355)$,

- knowledge acquisition from workers who work in an external R\&D unit, defined as a main tacit knowledge source, can positively influence the realization of $\mathrm{R} \& \mathrm{D}$ projects $(\operatorname{corr}=0.5056)$.

Unfortunately, similar research results from both German and Polish manufacturing enterprises were not received. We state that workers in German companies are aware of the importance of knowledge acquisition and, therefore, our research results received more meaningful and clearer relationships from the surveyed German companies. However, in order to build a structural model to identify the main tacit knowledge sources in a company, both internal and external, we present descriptive correlations for the main variables from a total of 85 Polish and German companies in a special joint crossborder region of Lubuskie, Poland, and Brandenburg, Germany (see Table 3).

Table 3. Research results

\begin{tabular}{|c|c|c|c|c|}
\hline $\begin{array}{l}\text { Construct/Item: } \\
\text { KS-KA-factor1/KS-KA-factor2/ KS-KA-factor3/ } \\
\text { KS-KA-factor4/ KS-KA-factor5 } \\
\text { IRD-factor1/ IRD-factor2/ IRD-factor3/ } \\
\text { IRD-factor4/ IRD-factor5 }\end{array}$ & Correlation & $\mathrm{r} 2$ & $\mathrm{t}$ & $\mathrm{p}$ \\
\hline Polish and German manufacturing companies: $\mathrm{KS}^{-\mathrm{KA}_{1} / \mathrm{IRD}}$ & 0.320113 & 0.102472 & 3.059752 & 0.002993 \\
\hline Polish and German manufacturing companies: $\mathrm{KS}^{-\mathrm{KA}_{2} / \mathrm{IRD}}$ & 0.304362 & 0.092636 & 2.893383 & 0.004880 \\
\hline Polish and German manufacturing companies: $\mathrm{KS}^{-\mathrm{KA}_{3} / \mathrm{IRD}}$ & 0.126950 & 0.016116 & 1.158962 & 0.249836 \\
\hline Polish and German manufacturing companies: $\mathrm{KS}^{-\mathrm{KA}_{4} / \mathrm{IRD}}$ & 0.155646 & 0.024226 & 1.426820 & 0.157429 \\
\hline Polish and German manufacturing companies: $\mathrm{KS}^{-\mathrm{KA}_{5} / \mathrm{IRD}}$ & 0.292116 & 0.085332 & 2.765860 & 0.007013 \\
\hline Polish and German manufacturing companies: $\mathrm{KS}^{-\mathrm{KA}_{6} / \mathrm{IRD}}$ & 0.175627 & 0.030845 & 1.615482 & 0.110048 \\
\hline Polish and German manufacturing companies: $\mathrm{KS}-\mathrm{KA}_{7} / \mathrm{IRD}$ & 0.366381 & 0.134235 & 3.565657 & 0.000609 \\
\hline
\end{tabular}


Therefore, based on the research results of a total of 85 manufacturing enterprises from the crossborder cooperative region of Lubuskie, Poland, and Brandenburg, Germany, where the companies were categorized as either construction or automotive, a structural model is presented (see Fig. 2).
This model includes the results of correlation analyses that estimate the effect of tacit knowledge sources on improving the realization of $R \& D$ projects in a company. The main tacit knowledge sources are identified - internal: manager and workers in the sales department, and external: external R\&D units.

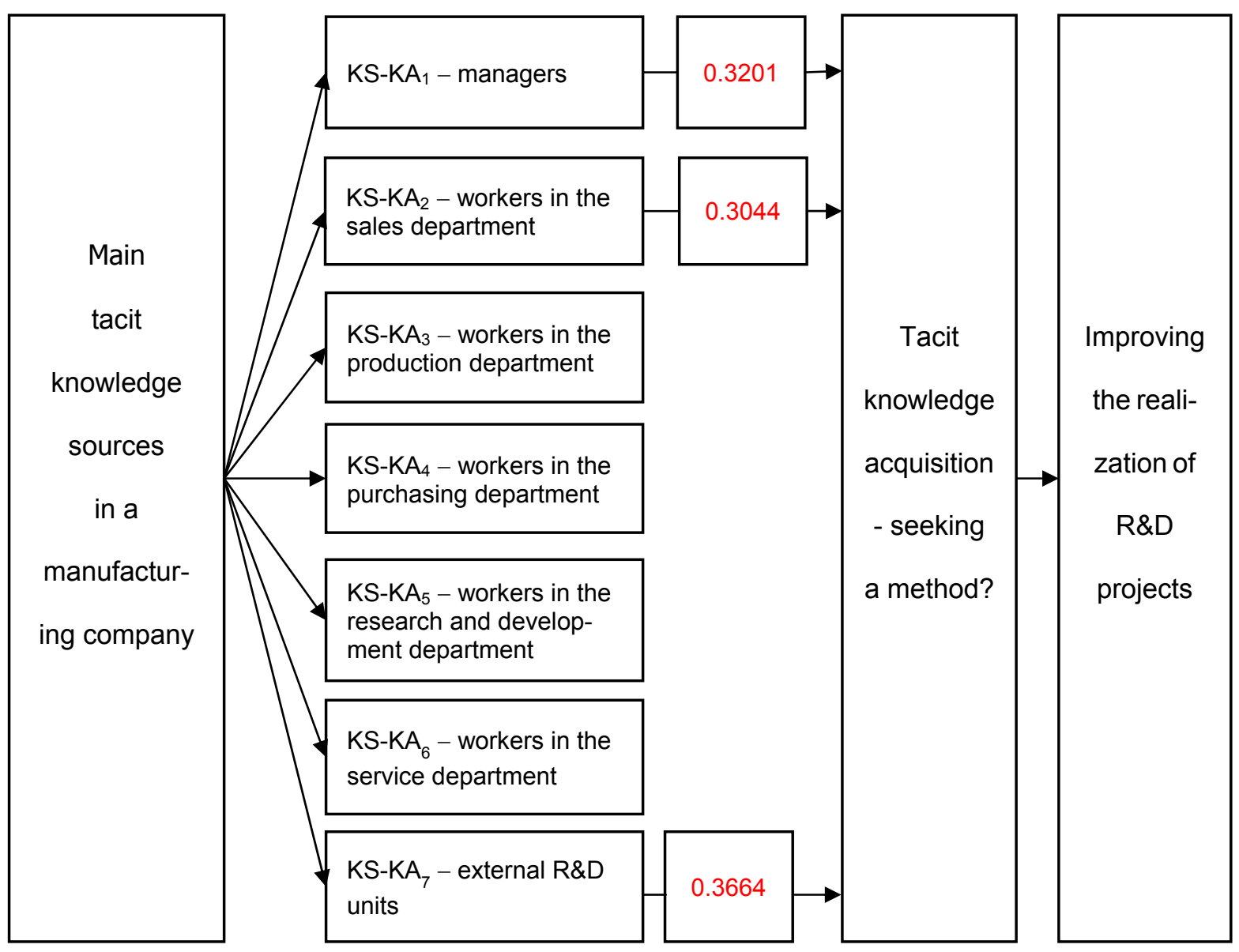

Figure 2. A structural model

According to the research results in this paper, a method for tacit knowledge acquisition will be developed, which includes knowledge from internal sources, managers and workers in the sales department, and from external sources, external $R \& D$ units.

\section{$4 \quad$ A method of knowledge acquisition in a manufacturing company}

The concept of tacit knowledge acquisition in a manufacturing company is discussed via an example of an R\&D department in a manufacturing company of the automotive SME sector that produces pneumatic components for braking systems and suspension systems in the utility vehicles.

On the basis of the research results from 85 Polish and German manufacturing companies, we have developed a method for knowledge acquisition from internal sources, managers and workers in the sales department, and from external sources, external R\&D units. 
The following methods are designed for an $R \& D$ department.

1. Knowledge acquisition from internal sources: the manager of a project ( $R \& D)$.

Method: completing a dedicated questionnaire consisting of closed questions.

The main role of the $\mathrm{R} \& \mathrm{D}$ department is to design an object in CAD programs, maintain contact with suppliers (present or new ones) with a request about the possibility of making a primary gasket, and choose the right technology from the available options.

A sample part of the questionnaire to be completed by the managers of projects:

1) Enter the ID of the project.

2) Enter sets of knowledge.

3) Enter the keywords for the issue.

4) Which department will use the knowledge?

5) What steps are made to solve the problem?

6) What are the key materials used for solving the problem (select or enter and attach)?

7) What materials were created to solve problems (select or enter and attach)?

2. Knowledge acquisition from internal sources: workers in the sales department.

Method: completing a dedicated questionnaire.

The proposed questionnaire is universal, so the one to be completed by the sales department has the same construction.

The main role of the sales department is the acquisition of new clients, contact with them, taking care of their needs, and eliciting the main requirements for their projects.

3. Knowledge acquisition from external sources: external R\&D units.

Method: consultation with experts from external R\&D units, asking about characteristic sheets and performing examinations of valves.
The main role of external $R \& D$ units is to act as experts in specific materials, for example, rubber. The R\&D unit should help in valve examinations using specialist equipment and provide support by task results and reports with interpretations.

Assumptions of the model for the acquisition of tacit knowledge showed via the example of projects carried out in the R\&D departments.

The characteristic of such a department is presented as follows:

$\mathrm{D}_{1}$ : company type: production, automotive sector,

$\mathrm{D}_{2}$ : company size: SME; current employment: about 70 workers,

$\mathrm{D}_{3}$ : project assumptions: pneumatic valves, assistive devices for assembly and production,

$\mathrm{D}_{4}$ : $\mathrm{R} \& \mathrm{D}$ personnel involved in the task: three to four people,

$\mathrm{D}_{5}$ : project budget: from 150,000 to $500,000 \mathrm{PLN}$,

$\mathrm{D}_{6}$ : project representative $>$ age 28 years,

$\mathrm{D}_{7}$ : R\&D manager: 15 years in the team, 17 years of experience in a similar position,

$D_{8}$ : number of projects carried out: five to six per year,

$\mathrm{D}_{9}$ : five employees.

The R\&D department has received a new project from a key account on a regular basis (see Fig. 3). The new project is to design a safety valve to be produced on a mass scale.

As a result of initial actions, the project manager identified the needs in terms of design and development. The people acting on behalf of the company are the vice-CEO and the chief designer (representative R\&D). The effect of having a meeting was the preparation of a report with findings. The results of the collected requirements of the new project are:

- material: brass,

- working parameters: $-40^{\circ} \mathrm{C}$ to $+80^{\circ} \mathrm{C}$,

- operating position: any - vertically, horizontally, at an angle, 


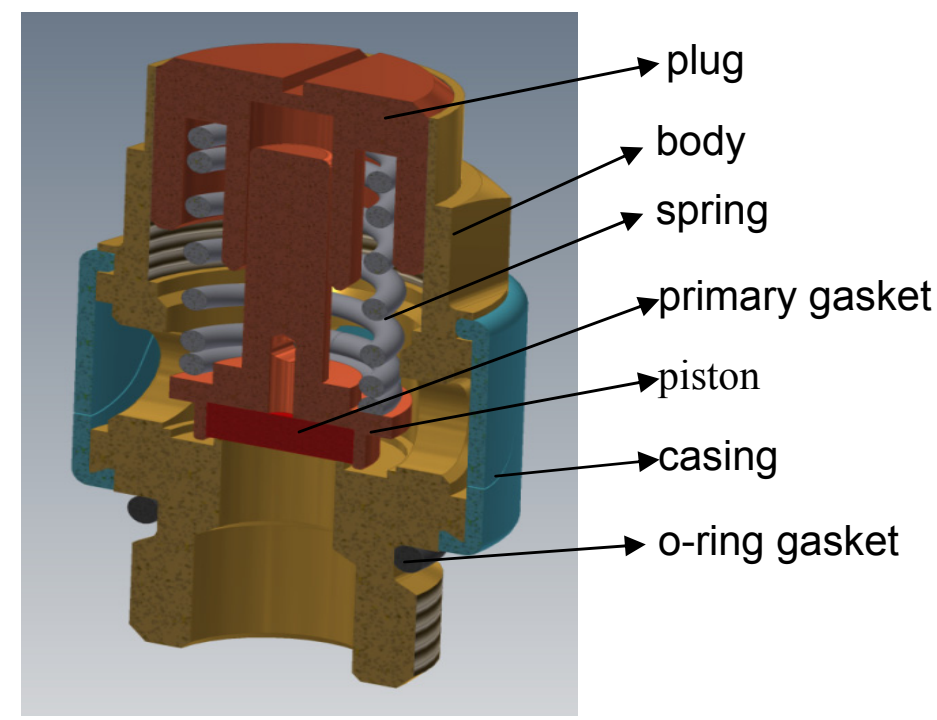

Figure 3. The safety valve, which is the subject of the new project in the R\&D department in the manufacturing company

- resistance to weather conditions: rain, frost, oil, grease, salt,

- opening pressure: nominally 10 bar (options: 12 , $8,9.5,14,13)$,

- at maximum flow: $100 \mathrm{l} / \mathrm{min}$,

- threaded connection: M16x1.5; M22x1.5.

After meeting with the team, a representative of the $\mathrm{R} \& \mathrm{D}$ department, the main designer said that as a result of work by the valve in new conditions, the team should design a new primary gasket. A different material for the primary gasket needed to be selected. Previously, a similar project design was functional between -30 and $+60^{\circ} \mathrm{C}$; however, the new design needed to be functional at the temperatures of $-40^{\circ} \mathrm{C}$. Therefore, it is necessary to acquire tacit knowledge from internal and external sources. According to the structural model and the proposed methods of acquiring knowledge, the authors propose the following activities.

1. Knowledge acquisition from internal sources: the manager of a project $(R \& D)$

Method: completing a dedicated questionnaire.

A sample part of the questionnaire to be completed by the managers of projects.

1) Enter the ID of the project.

$$
\text { Safety Valve_12.3 }
$$

2) Enter sets of knowledge.

Select: ...material....
3) Enter the keywords for the issue.

Select: ...gasket geometry, base gasket, rubber, technology...

4) Which department will use the knowledge? Select: ...R\&D, Sales department ...

5) What steps are made to solve the problem? Select:...Consultation with an internal expert: Jan Kowalski, R\&D Department

6) What are the key materials used for solving the problem (select/enter and attach)?

...project documentation: Safety Valve_10, CAD simulation: Safety Valve_ 10

7) What materials were created to solve problems (select or enter and attach)?

...project documentation: Safety Valve 12.3,CAD simulation: Safety Valve_ 12.3...

etc.

Results:

- designed the geometry of the gasket,

- selected the optimum technology for the manufacture of gaskets; there were the following options:

- option 1: cut with a rubber plate - rejected (because of the deformation of the side surface),

- option 2: cut with a rod of rubber - rejected (because of the micro-damage to the outer layer after cutting by the shield and a problem 
with the calibration of such a valve in a similar, earlier project),

- option 3: injection method (problematic material) - accepted,

- searched information about potential suppliers, checked costs,

- acquired knowledge of gasket and technical documentation.

2. Knowledge acquisition from internal sources: workers in the sales department

Method: completing a dedicated questionnaire.

A sample part of the questionnaire to be completed by the sales department.

1) Enter the ID of the project.

Safety Valve_12.3

2) Enter sets of knowledge.

Select: ... functionality....

3) Enter the keywords for the issue.

Select: ...gasket geometry, base gasket, customer, requirements....

4) Which department will use the knowledge?

Select: ...R\&D, Sales department ...

5) What steps are made to solve the problem?

Select: ...Feedback from customer: XYZ Company, external manager: Tomasz Nowak, $R \& D$ Department of XYZ Company

6) What are the key materials used for solving the problem (select or enter and attach)?

... general requirements of XYZ Company, client requirements of XYZ Company: Safety Valve_10

7) What materials were created to solve problems (select/enter and attach)?

...general requirements of XYZ Company (actualization), client requirements of XYZ Company:

Safety Valve_ 12.3

etc.

Results:

- gathered customer requirements for the functionality of the gasket,

- acquired knowledge about the supplier and customer requirements.
3. Knowledge acquisition from external sources: external $R \& D$ units

Method: consultation with experts from an external R\&D unit, asking about characteristic sheets and performing examinations of the valve.

Results:

- chosen material - obtained characteristic sheet of materials,

- commissioned analysis completed tightening of the valve after testing in a climate chamber (freezing or thawing) cycles,

- acquired knowledge about the specification of materials, research results with interpretation.

The knowledge acquired by the presented ways was then made available for sharing among employees; this is to act as an aid in solving similar problems. Moreover, based on the acquired information and knowledge, and at the management's discretion, it is advisable to update instructions for work on similar projects and make entries in employee handbooks.

\section{Conclusion}

Research results from the German and Polish manufacturing companies surveyed in this study show that the interaction of knowledge acquired from managers, the sales department, and the external R\&D units makes a significant contribution to an increase in the success of project realization in a company. We may also observe a need for building an awareness in Polish companies about the importance of knowledge acquisition and application tools to support this process. Thus, it is necessary to develop methods for tacit knowledge acquisition for a manufacturing company. Our case study presents the concept of how we can identify main tacit knowledge sources in an R\&D department. We hope that our approach will be useful for managers of companies because we are confident that the accumulation of knowledge can contribute to the success of a whole enterprise (e.g., business benefits: faster completion of projects, fewer corrections and complaints, reduction of training). This concept will be further developed in our future works. 
[1] Belussi, F., McDonald, F., Borrás, S., 2002. Industrial districts: State of the Art Review. Research Report, Project West-East id: Industrial Districts Re-location Processes; Identifying Policies in the Perspective of the European Union Enlargement. Report July 2005, [online] Available at: <http://cordis.europa.eu/docs/publications /1001/100123911-6_en.pdf $>$ [Accessed 3 November 2016].

[2] Bergamaschi, S., Martoglia, R., Sorrentino, S., 2012. A semantic method for searching knowledge in a software development context, In: Conference: Proceedings of the 20th Italian Symposium on Advanced Database Systems, SEBD 2012, June 24-27, 2012, Venice, pp.115122.

[3] Diallo, A., Thuillier, D., 2005. The Success of International Development Projects, Trust and Communication: an African Perspective. International Journal of Project Management, 23(3), pp.237-252.

[4] Drucker, P., 1964. Managing for Results, New York: Harper \& Row.

[5] Duda, J., 2015. Systemy informatyczne wspomagajace zarzadzanie wiedza (Informatics System Supporting Management of Knowledge).In: R. Knosala, ed., Innowacje w zarzadzaniu $i$ inżynierii produkcji. T. 2. Opole: Oficyna Wydawnicza Polskiego Towarzystwa Zarządzania Produkcja, pp.60-74.

[6] Falkenberg, L., Woiceshyn, J., Karagianis, J., 2003. Knowledge sourcing: internal or external? In: Competitiveness and Learning 5th International Conference, 30 May - 2 June, pp.1-17, [online] Available at: <http://www2.warwick. ac.uk/fac/soc/wbs/conf/olkc/archive/olk5/papers/ paper16.pdf $>$ [Accessed 15 November 2016].

[7] Gasik, S., 2011. A Model of Project Knowledge Management. Project Management Journal, 42(3), pp.23-44.

[8] Han, J., Kamber, M., Pei, J., 2012. Data Mining: Concepts and Techniques, Waltham: Elsevier Inc.

[9] Hu, Y., Yang, S.X., 2004. A Knowledge Based Genetic Algorithm for Path Planning of a Mobile Robot. In: Robotics and Automation. Proceed- ings. ICRA '04. 2004 IEEE International Conference. 26 April-1 May 2004.

[10] Internetowy System Aktów Prawnych (Internet System of Legal Acts), Dz. U. 2003 nr 32 poz. 262, [online] Available at:

$<$ http://isap.sejm.gov.pl/DetailsServlet?id=WDU 20030320262> [Accessed 20 November 2016].

[11] Kisielnicki, J., 2004. Zarzadzanie wiedzq we wspótczesnych organizacjach (Knowledge Management in Contemporary Organizations). In: A. Potocki ed., 2004, Zarzadzanie wiedza $w$ systemach informacyjnych, Wrocław: Wydawnictwo Akademii Ekonomicznej.

[12] Marcus, S., 1988. Automating Knowledge Acquisition for Expert Systems. Boston/ Dordrecht/ London: Kluwer Academic Publishers.

[13] Maurer, I., 2010. How to Build Trust in Interorganizational Projects: the Impact of Project Staffing and Project Rewards on the Formation of Trust, Knowledge Acquisition and Product Innovation. International Journal of Project Management, 28(7), pp.629-637.

[14] Nycz, M., 2011. Bussines Intelligence in Enterprise 2.0.In: M. Nycz ed., M.-L. Owoc, 2011, Prace naukowe Uniwersytetu Ekonomicznego we Wrocławiu $n r$ 232. Wrocław: Wydawnictwo Uniwersytetu Ekonomicznego, pp.79-89.

[15] Olbryś, J., 2007. Sieć bayesowska jako narzędzie pozyskiwania wiedzy z ekonomicznej bazy danych (Bayesian Network as a Tool of Extracting Knowledge from an Economic Database), Zeszyty Naukowe Politechniki Białostockiej, Informatyka, Zeszyt 93(2), pp.93-107.

[16] Patalas-Maliszewska, J., Krebs, I., 2015. Decision Model For the Use of the Application for Knowledge Transfer Support in Manufacturing Enterprises. In: W. Abramowicz ed., 2015. Business Information Systems Workshops: BIS 2015 International Workshops. LNBIP, Cham Heidelberg: Springer International Publishing Switzerland, 228, pp.48-55.

[17] Patalas-Maliszewska, J., Dudek A., 2016. A Model of a Tacit Knowledge Transformation for the Service Department in a Manufacturing Company: A Case Study. Foundations of Management, International Journal, Issue 8(1), pp.175-188. 
[18] Prodan, I., CoticSvetina, A., 2008. How Internal and External Sources of Knowledge Contribute to Firms' Innovation Performance, Managing Global Transitions, 6(3), pp.277-299.

[19] Śliwa, M., Patalas-Maliszewska, J., 2015. Model of Converting tacit Knowledge into Explicit Knowledge on the Example of R\&D Department of the Manufacturing Company, Including Evaluation of Knowledge Workers' Usefulness. Journal of Theoretical and Applied Computer Science, Vol. 9(3), pp.25-34.

[20] Tabaszewska, E., 2008. Nowoczesne koncepcje zarzqdzania - zarzadzanie wiedza (Modern Concepts of Management - Knowledge Management). Wrocław: Wydawnictwo Uniwersytetu Ekonomicznego.
[21] Wangare Wambui, T., Gachahi Wangombe, J., Wanjiku Muthura, M., 2013. Linking Human Resource Management to Knowledge Transfer for Organizational Development. International Journal of Business and Social Science, Vol. 4 No. 12, Special Issue - September 2013, pp.169183.

[22] Wąsowicz, M., 2013. Zarzqdzanie wiedza w portfelach projektów (Knowledge Management in Portfolios of Projects). In: G. Bełz ed., M. Hopej, A. Zgrzywa-Ziemak, 2013. Prace naukowe Uniwersytetu Ekonomicznego we Wroctawiu. Wiedza $w$ zarzadzaniu współczesna organizacja, No. 299, pp.130-137. 